Sherry Renata \& Hanafi Tanuwijaya

\title{
PELAKSANAAN PERJANJIAN HUTANG PIUTANG ATAS DASAR KEPERCAYAAN (STUDI PUTUSAN MAHKAMAH AGUNG REPUBLIK INDONESIA NOMOR:2683 K/Pdt./2016)
}

\author{
Sherry Renata \\ (Mahasiswa Program S1 Fakultas Hukum Universitas Tarumanagara) \\ (E-mail: sherryrenataa@hotmail.com)
}

\author{
Hanafi Tanawijaya S.H., M.H. \\ (Corresponding Author)
}

(Dosen Fakultas Hukum Universitas Tarumanagara. Meraih Sarjana Hukum pada Fakultas Hukum

Universitas Tarumanagara, Magister Hukum pada Fakultas Hukum Universitas Tarumanagara)

(E-mail: hanafitanawijaya@gmail.com)

\begin{abstract}
The agreement as described in Article $1313 \mathrm{KUHPer}$ is, an act of mutual adherence to one or more persons. The most common agreement in society is one of the accounts payable receivables. Receivable debt agreements orally are made solely by the words of the parties. The purpose of this writing is to find out how the settlement of the implementation of the loan receivables agreement contains elements of default. This research is a normative legal research. Type of data used is secondary data in the form of primary legal materials, secondary law materials, and non-law material. Technique of collecting data used is study of literature, instrument of research instrument is the decision of Supreme Court of Republic of Indonesia No: 2683 K/ Pdt.2016. The verdict on the case of default, ie between Soekotjo as Plaintiff and Melyani as Defendant. Claimed suicide on the ground has made a default on the verbal debt receivable agreement. Melyani denied the amount of the loan sued by Soekotjo because it was considered inappropriate. However, the judge decides that Melyani performs torture. Oral agreements have the power of law, as long as they are proved to have been made by the parties and have been in compliance with the legitimate terms of the agreement set forth in Article 1320 of the Civil Code.
\end{abstract}

Keywords: Oral Agreement, Legal, Breach of Contract

\section{PENDAHULUAN}

\section{A. Latar Belakang}

Manusia pada dasarnya merupakan subjek hukum yang hidup secara berkelompok dalam suatu wilayah tertentu dan di dalam kehidupannya terjadi 
adanya suatu interaksi satu dengan yang lain. Karena pada kodratnya manusia tidak dapat hidup sendiri, perlu adanya suatu interaksi satu dengan yang lain.

Semakin banyak interaksi yang terjadi semakin memungkinkan terjadinya suatu ikatan yang mengikatkan dirinya dengan masyarakat lain sehingga muncul adanya suatu perjanjian. Manusia sebagai mahluk sosial yang saling berinteraksi satu sama lain mengakibatkan adanya suatu ikatan satu sama lain, kegiatan ini bersifat privat. Aturan mengenai perikatan diatur dalam Buku ke III KUHPer. Dalam Buku ke III KUHPer pasal 1313 mengatakan yaitu "suatu perjanjian adalah suatu perbuatan dengan mana satu orang atau lebih mengikatkan dirinya kepada satu orang atau lebih lainnya." Salah satu masalah mengenai perjanjian yang sering kita jumpai dalam masyarakat adalah mengenai perjanjian hutang piutang.

Pada dasarnya perjanjian akan berjalan tanpa adanya hambatan apabila, pihak dalam perjanjian yang melaksanakan perjanjian tersebut dilandasi oleh itikad baik dan melaksanakan kewajibannya sesuai dengan apa yang telah diperjanjikan di awal kesepakatan.

Namun, apabila dalam melaksanakan perjanjian terdapat salah satu pihak yang tidak memenuhi kewajibannya, maka akan terjadi adanya wanprestasi. Mengenai perbuatan wanprestasi ini yang terjadi dalam perkara No.2683/K/Pdt.2016 merupakan perkara gugatan wanprestasi yang diajukan oleh Soekotjo sebagai Penggugat yang mengajukan gugatan terhadap Melyani Wijaya sebagai Tergugat.

Gugatan yang diajukan oleh Penggugat kepada Tergugat yang merupakan kerjasama/ rekan kerja suami Tergugat yang bernama Jusuf Eddy Sugianto sejak tahun 1995 dalam bidang usaha jual beli gabah. Setelah suami Tergugat meninggal, Tergugat meminta bantuan kepada Penggugat agar diberi kepercayaan untuk melanjutkan hubungan kerjasama yang terjalin antara Penggugat dan suami Tergugat, akhirnya Penggugat memberi kepercayaan 
kepada Tergugat dengan memberi pinjama modal usaha guna mencari gabah dengan kewajiban gabah tersebut harus dijual kepada Penggugat sebagai pemberi pinjaman modal (nota bon).

Pada awalnya kerjasama yang terjalin antara Penggugat dan Tergugat berjalan baik, akan tetapi sejak tahun 2010 Penggugat merasakan upaya tidak benar terhadap pinjaman modal usaha yang diberikan oleh Penggugat secara kumulatif sebesar Rp. 170.000.000,00 (seratus tujuh puluh juta Rupiah).

Menurut Pasal 1243 KUHPer, yaitu "Penggantian biaya, kerugian dan bunga karena tak dipenuhinya suatu perikatan mulai diwajibkan, bila debitur, walaupun telah dinyatakan lalai, tetap lalai untuk memenuhi perikatan itu, atau jika sesuatu yang harus diberikan atau dilakukannya hanya dapat diberikan atau dilakukannya dalam waktu yang melampaui waktu yang telah ditentukan.” Maka dapat dikata bahwa debitur tetap lalai karena tidak memenuhi sesuatu yang sudah diperjanjikan dna kreditur merasa dirugikan oleh kelalain yang dilakukan oleh debitur.

Berdasarkan penjelasan latar belakang yang telah dipaparkan oleh penulis sebelumnya, maka penulis merasa tertarik untuk melakukan kajian lebih lanjut mengenai topik ini secara komprehensif dan menuangkannya dalam bentuk proposal skripsi dalam judul PELAKSANAAN PERJANJIAN HUTANG PIUTANG ATAS DASAR KEPERCAYAAN (STUDI PUTUSAN MAHKAMAH AGUNG REPUBLIK INDONESIA NOMOR:2683 K/Pdt./2016).

\section{B. Perumusan Masalah}

Berdasarkan latar belakang permasalahan di atas, perumusan masalah yang akan dibahas dalam penulisan hukum ini adalah, sebagai berikut :

1. Bagaimana kekuatan alat bukti yang diajukan oleh para pihak adanya perjanjian hutang piutang secara lisan? 
2. Bagaimana pertimbangan hukum hakim dalam menentukan pembuktian hutang piutang yang dilakukan secara lisan?

\section{Metode Penelitian}

Untuk mengetahui masalah-masalah dan agar penulis dapat melakukan evaluasi dari pokok permasalah yang telah disebutkan, sehingga dalam pengumpulan bahan-bahan, fakta-fakta, dan data yang diperlukan penulis menggunakan metode sebagai berikut :

1. Jenis Penelitian

Metode penelitian yang penulis gunakan dalam penulisan proposal ini adalah metode penelitian hukum normatif. Penelitian hukum normatif adalah suatu proses untuk menemukan suatu aturan hukum, prinsip-prinsip hukum, maupun doktrin-doktrin hukum untuk menjawab permasalahan hukum yang dihadapi. ${ }^{1)}$

2. Sifat Penelitian

Sifat penelitian yang penulis gunakan dalam penulisan proposal ini adalah preskriptif. Penulis melakukan penilaian mengenai apa yang seharusnya dilakukan berupa sebuah solusi. Sebagai ilmu yang bersifat preskriptif, ilmu hukum mempelajari tujuan hukum, nilai-nilai keadilan, validitas aturan hukum, konsep-konsep hukum, dan norma-norma hukum. Sebagai ilmu terapan, ilmu hukum menetapkan standar prosedur, ketentuan-ketentuan, rambu-rambu dalam melaksanakan aktivitas hukum. ${ }^{2)}$

3. Sumber Bahan Hukum

a. Bahan hukum primer yaitu bahan hukum yang bersifat mengikat, dalam hal ini penulis menggunakan peraturan perundang-undangan yang

\footnotetext{
${ }^{1)}$ MuktiFajar ND dan YuliantoAchmad, Dualisme Penelitian Hukum Normatif dan Empiris, (Yogyakarta: PustakaBelajar,2010), hal.34.

2) Peter Mahmud Marzuki, Penelitian Hukum, (Jakarta: Kencana Prenada Media Group,2010), hal.32.
} 
berkaitan dengan proposal ini, yaitu Kitab Undang-Undang Hukum Perdata.

b. Bahan hukum sekunder adalah publikasi hukum yang berupa dokumendokumen tidak resmi. Publikasi tersebut terdiri atas:

1) Buku-buku hukum

2) Kamus hukum

3) Makalah-makalah

4) Artikel dan internet

c. Bahan Non Hukum yaitu bahan yang digunakan untuk memperoleh pemahan sudut pandang objek yang penulis teliti, dalam hal ini penulis menggunakan Kamus Besar Bahasa Indonesia (KBBI) dan wawancara dengan narasumber (ahli hukum) sebagai upaya mendapatkan pendapat hukum tentang objek yang diteliti.

4. Teknik Pengumpulan Bahan Hukum

Pengumpulan bahan hukum dimaksudkan untuk memperoleh bahan hukum dalam penelitian dan mempunyai relevansi dalam bidang non hukum. Dalam pengumpulan data penulis menggunakan studi pustaka (library research). Yaitu suatu cara untuk memperoleh data melalui penelitian kepustakaan, dimana penulis mencari data dengan membaca buku-buku, bahan kuliah, dan berbagai peraturan perundang-undangan. Studi pustaka adalah suatu alat pengumpulan bahan hukum yang dilakukan melalui bahan hukum tertulis (content analysis).

5. Teknik Analisis Bahan Hukum

Menurut Peter Mahmud Marzuki yang mengutip pendapat Philipus M. Hadjon memaparkan metode deduksi sebagaimana silogisme yang diajarkan oleh Aristoteles. Penggunaan metode deduksi berpangkal dari pengajuan premis mayor. Kemudian diajukan premis minor, dari kedua 
premis itu kemudian ditarik suatu kesimpulan atau conclusion. ${ }^{3)}$ Analisis data yang digunakan dalam penelitian ini adalah dengan logika deduktif. Yaitu menjelaskan suatu hal yang bersifat umum kemudian menariknya menjadi kesimpulan yang lebih khusus. Analisis yang dilakukan dengan melakukan telaah atas isu hukum yang diajukan berdasarkan bahan-bahan yang telah dikumpulkan dengan menarik kesimpulan dalam bentuk argumentasi.

\section{PEMBAHASAN}

\section{A. Kekuatan Alat Bukti yang Diajukan oleh Para Pihak Adanya Perjanjian} Hutang Piutang secara Lisan

Perjanjian menurut KUHPer Pasal 1313 yang menyatakan bahwa "Perjanjian atau persetujuan adalah suatu perbuatan dengan mana satu orang atau lebih mengikatkan dirinya terhadap satu orang atau lebih."

Sehingga dapat diketahui syarat-syarat sahnya suatu perjanjian yang telah diatur dalam Pasal 1320 KUHPerdata :

1. Sepakat mereka yang mengikatkan dirinya

Kata sepakat dalam perjanjian mempunyai arti yaitu, perjanjian dibuat dengan izin para pihak tanpa adanya suatu paksaan atau penipuan, kedua pihak yang telah mengadakan perjanjian itu sepakat mengenai hal-hal pokok dari perjanjian yang telah diperjanjikan itu. ${ }^{4}$

2. Kecakapan untuk membuat suatu perikatan

Orang yang ingin membuat suau perjanjian harus memenuhi syarat-syarat menurut hukum. Dalam Pasal 1330 KUHPerdata disebut kriteria dari orangorang yang tidak cakap untuk membuat suatu perjanjian :

a. Orang-orang yang belum dewasa

\footnotetext{
${ }^{3)}$ Peter Mahmud Marzuki, Op.Cit.,hal.47.

${ }^{4)}$ R. Subekti, Hukum Perjanjian, hal.17
} 
b. Mereka yang ditaruh dibawah pengampuan

c. Orang perempuan dalam hal-hal yang ditetapkan oleh undang-undang dan semua orang kepada siapa undang-undang telah melarang membuat suatu perjanjian-perjanjian tertentu, tetapi dengan adanya SEMA No.3/1963 yang menyatakan bahwa seorang istri untuk melakukan suatu perbuatan melawan hukum untuk menghadap di depan pengadilan tanpa izin atau bantuan dari suaminya sudah tidak berlaku lagi. ${ }^{5)}$

3. Suatu hal tertentu

Suatu perjanjian yang terjadi harus mengenai suatu hal tertentu mengenai, artinya apa yang diperjanjikan hak-hak dan kewajiban kedua belah pihak jika timbul suatu masalah. Barang yang dimaksudkan dalam perjanjian paling sedikit harus ditentukan jenisnya agar jelas hal apa yang sedang diperjanjikan. ${ }^{6}$

4. Sebab yang halal

Kata "Causa" berasal dari Bahasa latin artinya "sebab" dan dalam Bahasa Belanda "Oorzaak". Tetapi yang dimaksud dengan Causa yang halal dalam Pasal 1320 KUHPerdata bukanlah sebab dalam arti yang menyebabkan atau yang mendorong orang membuat suatu perjanjian, melainkan sebab dalam arti "isi perjanjian itu sendiri", yang menggambarkan tujuan yang akan dicapain oleh pihak-pihak. ${ }^{7)}$

Pasal 1320 KUH Perdata mengenai syarat sahnya perjanjian lisan tidak secara langsung mengatur mengenai bentuk dari adanya suatu perjanjian, sehingga dalam membuat perjanjian, masyarakat dibebaskan untuk menentukan bentuk dari perjanjian tersebut. Membuat perjanjian yang dilakukan secara lisan tetap dapat dikatakan sah, selama perjanjian tersebut telah memenuhi syarat dari sahnya

\footnotetext{
${ }^{5)}$ Ibid.

6) R.Subekti,Op.Cit,hal.18

${ }^{7)}$ Ibid
} 
perjanjian yang tercantum dalam Pasal 1320. Perjanjian lisan dapat dikatakan sah atau sesuai dengan peraturan selama tidak ada undang-undang yang menentukan bahwa perjanjian yang dibuat harus berupa suatu tulisan atau berupa bentuk fisik Berdasarkan uraian yang di atas, perjanjian yang dilakukan secara langsung/lisan, sehingga jika terjadi wanprestasi atau seseorang tidak melakukan apa yang seharusnya ia lakukan di awal perjanjian yang telah disepakati Bersama atau disepakati oleh kedua belah pihak dalam perjanjian yang dilakukan secara lisan, perjanjian yang dilakukan secara langsung tersebut dapat dijadikan dasar untuk menyatakan seseorang telah melakukan ingkar janji. Tanpa sadar sebetulnya perjanjian lisan adalah perjajian yang sering kita jumpai dalam kehidupan masyarakat atau dalam kehidupan sekitar. Perjanjian lisan sering kali kita temui dalam perjanjian yang sederhana atau tidak rumit. Yang dimaksud tidak rumit adalah perjanjian yang tidak mengakibatkan adanya suatu kerugian yang besar.

Salah satu bentuk perjanjian yang sering kita temui di masyarakat adalah perjanjian hutang piutang. Perjanjian hutang piutang termasuk kedalam perjanjian pinjam meminjam yang diatur dalam Pasal 1754 KUHPer yang menyatakan, "Pinjam meminjam ialah perjanjian dengan mana pihak yang satu memberikan kepada pihak yang lain suatu jumlah tertentu barang-barang yang habis karena pemakaian, dengan syarat bahwa pihak yang belakangan ini akan mengembalikan sejumlah yang sama dari macam dan keadaan yang sama pula." Hutang adalah suatu kewajiban yang biasanya dinyatakan berupa nominal uang yang dilakukan secara langsung maupun yang akan timbul dikemudian hari. Apabila debitur tidak dapat memenuhi atau melunasi hutang apa yang telah disepakati di awal perjanjian maka kreditur mempunyai hak untuk mendapat pemenuhannya dari harta kekayaan debitur. Di dalam perjanjian hutang piutang, orang yang memberi pinjaman disebut sebagai Kreditur sedangkan yang menerima pinjaman disebut sebagai Debitur. 
Pihak debitur maupun kreditur mempunyai kewajiban masing-masing. Salah satu dari kewajiban debitur adalah mengembalikan pinjaman hutang yang telah ia pinjam dalam jumlah yang sesuai di awal perjanjian dan dalam jangka waktu yang telah disetujui di awal perjanjian. Apabila, terdapat bunga dalam peminjaman uang tersebut, debitur wajib untuk membayar bunga yang telah diperjanjikan. Sedangkan, kewajiban dari kreditur adalah ia dapat mengajukan gugatan kepada Pengadilan Negeri atau mengajukan tuntukan kepada debitur, apabila debitur tidak mengembalikan uang yang telah dipinjamkan oleh pihak kreditur.

Apabila kreditur merasa dirugikan oleh debitur dan ingin mengajukan gugatan ke pengadilan, maka kreditur harus mempunyai alat bukti yang kuat untuk membuktikan bahwa benar telah terjadi adanya suatu perjanjian. Terutama mengenai perjanjian yang dilakukan secara lisan perlu suatu bukti yang cukup kuat. Mengenai pembuktian telah diatur dalam Pasal 283 RBg/163 HIR yang menyatakan, "bahwa barangsiapa mengatakan mempunyai suatu hak atau mengemukakan suatu perbuatan untuk meneguhkan haknya itu, atau untuk membantah hak orang lain, haruslah membuktikan adanya perbuatan itu." Dari bunyi pasal tersebut dapat diketahui bahwa pihak yang memiliki hak dalam suatu perbuatan yang telah terjadi, ia dapat melakukan tindakan lanjut terhadap perbuatan yang telah terjadi atau menjelaskan bahwa benar telah terjadi suatu peristiwa, dan pihak tersebut perlu membuktikan bahwa adanya hak dari pihak yang bersangkutan.

Perjanjian secara lisan bisa dipakai, karna perjanjian itu merupakan ikatan hukum dari suatu pihak dan pihak yang lain. Perjanjian antara 2 orang itu sendiri, bukan orang lain karna itu hanya mengikat 2 orang tidak termasuk orang lain. Perjanjian tidak tertulis juga termasuk mengikat, namun oleh tergugat diingkari karna tergugat tidak menjual seharusnya dijual tetapi apakah tergugat meminjam. Bisa jadi termasuk ke dalam wanprestasi asal bisa dibuktikan bahwa si tergugat 
telah melakukan wanprestasi yaitu melanggar perjanjian. Kekuatan alat bukti terletak pada pengakuan. Pengakuan dari pihak yang piutang dan pihak berhutang, dan juga penyerahan barang/uang buktinya ada dari situ.

Dalam suatu kasus perkara untuk melakukan adanya pembuktian tidak hanya pihak Penggugat saja yang harus membuktikan dalilnya. Tidak semua yang menjadi dasar dari gugatan Penggugat harus dibuktikan seluruh kebenarannya, sesuatu yang tidak disangkal maupun diakui sepenuhnya tidak perlu untuk melakukan pembuktian.

Dalam membuktikan suatu perkara perlu adanya suatu alat bukti yang menguatkan gugatan dari Penggugat. Alat bukti menurut M.Yahya Harahap, alat bukti (bewijsmoddle) adalah alat yang berbentuk dan suatu jenis yang dapat memudahkan dalam memberikan suatu penjelasan terhadap pokok perkara yang terjadi untuk membantu memudahkan hakim dalam mengambil keputusan di peradilan

Dalam pembuktian perlu adanya suatu alat bukti yang menguatkan gugatan dari Penggugat. Alat bukti dalam perkara perdata sesuai dengan Pasal 164 HIR serta Pasal 1886 KUHPerdata, antara lain :

1. Alat bukti surat

Alat bukti surat adalah salah satu alat bukti fisik yang paling penting untuk dan paling utama dalam hal pembuktian. Alat bukti surat dapat berupa surat otentik dan surat dibawah tangan (tidak otentik).

2. Alat bukti saksi

Alat bukti saksi adalah orang yang melihat, mendengar atau mengalami kejadian yang diperkarakan. Dalam peradilan perdata terdapat istilah unus testis nulus testis (Pasal 1905 KUHPerdata), seorang saksi tanpa adanya 
suatu alat bukti lain tidak dapat dipercaya sehingga saksi yang harus diajukan harus lebih dari 1 orang.

3. Alat bukti persangkaan

Dalam Pasal 1915 KUHPerdata menyebutkan, “dugaan adalah kesimpulan yang diambil dari ketentuan undang-undang atau oleh hakim tentang suatu kejadian yang dikenal, dapat diketahui adanya sesuatu kejadian yang tidak dikenal."

4. Alat bukti pengakuan

Dengan adanya pengakuan dari salah satu pihak maka tidak diperlukan lagi suatu pembuktian (Pasal 1923 KUHPerdata). Engakuan dapat dilakukan di dalam persidangan yang sedang berlangsung maupun diluar persidangan. Apabila dilakukan di dalam persidangan dapat memperkuat bukti, sedangkan apabila dilakukan di luar persidangan bukti tersebut hanya dapat diserahkan kepada hakim dan berdasarkan kebijaksanaan hakim.

5. Alat bukti sumpah

Dalam Pasal 1929 yang menyatakan "suatu pernyataan hikmat yang dikemukakan secara sungguh-sungguh dengan menyebut nama Tuhan Yang Maha Esa sesuai dengan yang memberikan sumpah.

Perjanjian dapat dilakukan secara lisan maupun secara tertulis. Perjanjian lisan adalah perjanjian yang terjadinya karena adanya suatu kesepakatan satu sama lain tanpa adanya suatu bukti yang tertulis. Perjanjian yang dilakukan secara lisan biasanya terjadi kareng sudah saling mengenal satu sama lain atau adanya sebuah hubungan keluarga maka dari itu dalam perjanjian yang dilakukan secara lisan sangat dibutuhkan adanya kepercayaan.

Menurut Teori Kepercayaan, tidak semua pernyataan melahirkan adanya suatu perjanjian. Suatu pernyataan hanya akan menimbulkan adanya perjanjian apabila pernyataan tersebut menurut kebiasaan yang berlaku di dalam kehidupan 
masyarakat yang menimbulkan adanya suatu kepercayaan bahwa hal yang dinyatakan memang benar dikehendaki.

Mengenai kasus yang terjadi antara Soekotjo dan Melyani bahwa Melyani meminjam uang sebagai modal usaha guna mencari gabah dan kesepakatan itu terjadi atas dasar kepercayaan tanpa adanya perjanjian hitam di atas putih. Karena sebelumnya Soekotjo telah menjalin kerjasama selama belasan tahun dengan almarhum suami Melyani dan tidak pernah terjadi masalah, maka dari itu Soekotjo menyetujui atas permohonan pinjaman uang dari Melyani. Namun, dengan kewajiban gabah tersebut harus dijual kepada penggugat sebagai pemberi pinjaman modal (Nota Bon).

Kerjasama yang terjalin antara Melyani dan Soekotjo pun berjalan dengan baik pada awalnya, hingga pada tahun 2010 terjadi ketidakseimbangan antara modal yang dipinjam oleh Melyani dengan gabah yang dimasukkan/dijual Melyani di Gudang selep milik Soekotjo. Akhirnya Soekotjo mencari tau aktivitas yang dilakukan oleh Melyani dan ternyata aktivitas membeli gabah dialihkan oleh Melyani untuk menerima gadai sawah tanpa sepengetahuan dan tanpa seijin dari Soekotjo.

Perbuatan yang dilakukan oleh Melyani dapat dikatakan termasuk wanprestasi karena ia tidak mengembalikan uang yang telah dipinjam dan mengambil keuntungan untuk dirinya sendiri dari modal yang telah dipinjamkan oleh Soekotjo. Namun, Melyani pun membantah karena ia pun merasa dirugikan dan mengatakan bahwa tidak ada perjanjian hitam di atas putih, yang ada kepercayaan.

Ganti rugi akibat terjadinya wanprestasi dalam KUHPer diatur dalam Pasal 1243 yang mengatakan bahwa Penggantian biaya, kerugian dan bunga karena tak dipenuhinya suatu perikatan mulai diwajibkan, bila debitur walaupun telah memberikan atau telah melakukan yang telah diperjanjikan namun telah melewati 
batas waktu yang telah diperjanjikan di awal perjanjian yang telah disepakati oleh kedua belah pihak. Ganti rugi dapat berupa biaya, rugi, dan bunga.

Dalam kasus ini, Penggugat telah membebankan adanya bunga sebesar 1,5\% yang dirupiahkan sebesar Rp.1.050.000,00 (satu juta lima puluh ribu rupiah) dan Tergugat mengatakan bahwa ia telah membayar bunga dari hutang setiap bulannya selama 5 tahun. Penggugat mengatakan bahwa ia menderita kerugian secara materiil Rp.170.000.000,00 (seratus tujuh puluh juta rupiah) namun, Tergugat mengatakan bahwa Rp.169.000.000,00 (seratus enam puluh Sembilan juta rupiah) kalau 170 juta itu ditambah bunga 1 bulan lagi karena belakangan Tergugat terkena bunga sebesar 1,5\% atau Rp.1.050.000.

Dalam kasus ini, antara Penggugat dan Tergugat telah terjadi adanya suatu kesepakatan. Apabila telah ada kesepakatan maka dapat dikatakan sebagai suatu perjanjian sesuai dengan Asas Konsensualisme, yaitu pada dasarnya perjanjian dan perikatan yang timbul karenanya itu sudah dilahirkan sejak detik tercapainya kesepakatan. Perjanjian sudah sah apabila sudah sepakat mengenai hal-hal yang pokok dan tidaklah diperlukan sesuatu formalitas. asas perjanjian itu teori perjanjian dalam KUHPer boleh lisan boleh tertulis, maka perjanjian lisan dianggap sah. Perjanjian tertulis hanya digunakan sebagai alat bukti, mereka memilih perjanjian lisan dimana berdasarkan kepercayaan, maka kalo kemudian timbul masalah yang dicari adalah alat bukti.

Alat bukti yang digunakan dalam persidangan ini sudah pasti saksi, persyaratan sebagai saksi sudah terpenuhi atau tidak, teori alat bukti mengatakan bahwa satu saksi tidak dianggap sebagai saksi. Namun, dapat kita ketahui apabila perjanjian yang dilakukan secara lisan akan memungkinkan adanya salah satu pihak yang menyangkal karena tidak adanya bukti yang dilakukan secara tertulis. Apabila Tergugat menyangkal maka perlu adanya suatu alat bukti yang menguatkan bahwa 
benar telah terjadi perjanjian antara Penggugat dan Tergugat. Perlu diketahui risiko dari adanya perjanjian lisan yaitu lemah dalam hal pembuktian.

Keterangan saksi yang diberikan baik dari pihak Penggugat maupun Tergugat tidak memenuhi syarat saksi yang telah diatur. Karena keduanya merupakan saksi yang bekerja dengan Penggugat maupun Tergugat sehingga tidak dapat dikatakan sebagai alat bukti karena syarat materiil sebagai saksi tidak terpenuhi sehingga tidak mempunyai kekuatan pembuktian. Maka alat bukti, saksi yang diajukan tidak dapat diterima. Karena, keterangan saksi yang bersumber dari keterangan orang lain dikatakan sebagai keterangan sebagai testimonium de auditu, yaitu keterangan saksi yang hanya bersumber atau berdasar pada keterangan yang didapatkan dari orang lain tanpa mendengar, melihat, dan mengalami peristiwa hukumnya.

Mengenai kekuatan alat bukti dalam pembuktian dalam kasus ini, cukup satu alat bukti sudah cukup dan berdasarkan apa yang telah diatur, bukti yang telah diserahkan yang dapat digunakan sebagai alat bukti bahwa telah terjadi adanya perjanjian yaitu adanya pengakuan dari pihak Tergugat bahwa ia memang benar meminjam uang kepada Penggugat serta adanya bukti catatan dari Penggugat berupa catatan pinjaman modal.

Menurut Ibu Anda Setiawati S.H.,M.H. Sanksi nya betul yaitu, ganti rugi, pembatalan perjanjian, peralihan resiko, dan membayar biaya perkara. Permohonan si A (Penggugat) telah dipenuhi yaitu dengan agar uangnya dikembalikan. Pembatalan perjanjian artinya antara si A dan si C (Tergugat) selesai, tetapi uang yang telah dipinjam oleh si C tetap harus dikembalikan karna pembatalan perjanjian bukan berarti debiturnya terbebas dari kewajibannya.

Ketika terjadi pembatalan perjanjian, keadaannya kembali seperti semula lagi. Kalau ada perbuatan yang sudah dilakukan itu dapat dituntut kembali. Mengenai peralihan resiko, apabila terjadi kerugian. Kalau kerugian itu menjadi tanggung 
jawab A yaitu berupa kerugian materiil. Ganti rugi dalam wanprestasi itu diatur dalam Pasal 1243,1247, dan 1248 KUHPer mengenai ganti rugi yang membatasi sewenang-wenangnya debitur. A harus meminta ganti rugi secara wajar.

Kekuatan alat bukti apabila tidak dilakukan secara tertulis tetap terjadi adanya suatu perjanjian sesuai dengan asas yang berlaku. Untuk saksi yang diajukan oleh Penggugat maupun Tergugat tidak dapat dikatakan sebagai saksi karna merupakan orang yang bekerja kepada pihak Tergugat maupun Penggugat, maka untuk saksi apabila diajukan sebagai salah satu alat bukti tidak dapat digunakan sebagai pembuktian karena tidak memiliki kekuatan alat bukti. Kekuatan alat bukti terletak pada adanya pengakuan. Pengakuan dari pihak yang piutang dan pihak yang berhutang dan juga adanya penyerahan barang/uang buktinya ada dari situ. Mengajukan alat bukti untuk membuktikan bahwa benar telah terjadi adanya perjanjian sangat dibutuhkan dalam persidangan. Dalam syarat sahnya suatu perjanjian dalam Pasal 1320 KUH Perdata tidak mengharuskan bahwa dalam perjanjian perlu adanya saksi, namun apabila ada saksi dalam pelaksanaan perjanjian tersebut dapat memudahkan dalam hal pembuktian apabila terjadi penyalahgunaan dari perjanjian yang telah disepakati tersebut. Apabila diminta ganti rugi berupa sertifikat adalah salah. Apabila dilihat dalam mekanisme UU Hak Tanggungan No. 4 tahun 1996 menyebutkan bahwa jaminan hutang berupa tanah itu dipersyaratkan harus dengan APHT. Kalau memang harus memberikan jaminan kepada A harus dibuktikan dengan berupa suatu akta otentik, dalam kasus ini tidak ada APHT maka tidak bisa.

Berdasarkan hasil wawancara oleh penulis dan menurut Analisa dari penulis, penulis berpendapat bahwa kelemahan dari perjanjian yang dilakukan secara lisan adalah memang betul dalam hal pembuktian. Maka dari itu kekuatan alat bukti dalam hal ini merupakan sesuatu yang penting untuk membuktikan apakah telah terjadi suatu perjanjian antara kedua belah pihak. Karna apabila, salah satu 
menyangkal kalau tidak pernah melakukan perjanjian tidak memiliki alat bukti yang kuat karena tidak dilakukan secara tertulis. Maka dari itu perlu ada nya halhal lain yang membuktikan bahwa benar telah terjadi perjanjian, setelah adanya bukti bahwa benar telah terjadi perjanjian setelah itu harus membuktikan bahwa benar jumlah yang ditagih oleh Penggugat bukan merupakan suatu rekayasa atau dilebih-lebihkan oleh Penggungat dengan maksud untuk mencari keuntungan.

Dalam kasus ini, dapat dilihat bahwa alat bukti yang dapat digunakan adalah adanya pengakuan. Karena, saksi yang digunakan tidak dapat digunakan karna bukan merupakan saksi yang melihat dan mendengar di saat kejadian itu berlangsung. Melainkan, saksi tersebut adalah pekerja yang bekerja dengan Penggugat maupun Tergugat. Dan sebetulnya pengakuan dari Tergugat sudah cukup untuk menguatkan bahwa benar telah terjadi suatu transaksi pinjam meminjam uang untuk usaha dan Tergugat juga tidak menyangkal namun hanya membela diri dengan cara mengatakan bahwa ia juga mengalami kerugian tanpa maksud untuk mencari keuntunga sendiri serta ia juga mengatakan bahwa ia telah membayar bunga yang telah diajukan dari pihak Penggugat maka itu sudah merupakan alat bukti yang kuat bahwa benar telah terjadi Perjanjian antara Penggugat dan Tergugat.

Kelemahan dari perjanjian yang dilakukan secara lisan yaitu dalam hal pembuktian. Namun kekuatan alat bukti yang tidak dilakukan secara tertulis tetap terjadi adanya perjanjian. Dalm hal ganti rugi, penggugat meminta ganti rugi berupa sertifikat hak milik yang sebelumnya tidak pernah dibahas dalam awal perjanjian. Itu tidak dapat dijadikan sebagai penyerahan jaminan, karna penggugat meminta jaminan tersebut ketika perjanjian tersebut telah berjalan. Maka seharusnya hakim tidak menyetujui untuk menyerahkan objek jaminan tersebut, karena tidak sesuai dengan mekanisme yang berlaku Bahwa betul yang dikatakan oleh Prof. Abdul Gani yang mengatakan bahwa saksi tidak dapat diterima karena 
saksi yang diajukan baik dari pihak penggugat maupun dari pihak tergugat bukanlah saksi yang mendengar maupun menyaksikan secara langsung. Melainkan, adalah saksi yang bekerja dengan penggugat maupun tergugat maka saksi tersebut dianggap tidak sah. Dan dibenarkan bahwa dalam hal penyerahan sertifikat apabila tidak diperjanjikan di awal tidak bisa digunakan sebagai jaminan.

\section{B. Pertimbangan Hukum Hakim dalam Menentukan Pembuktian Hutang Piutang yang Dilakukan secara Lisan}

Pada pasal 5 Undang-Undang No. 48 Tahun 2009 tentang Kekuasaan Kehakiman, dikatakan "hakim adalah hakim pada Mahkamah Agung dan hakim pada badan peradilan yang berada di bawahnya dalam lingkungan peradilan umum, lingkungan peradilan agama, lingkungan peradilan militer, lingkungan peradilan tata usaha negara, dan hakim pada pengadilan khusus yang berada dalam lingkungan peradilam tersebut." Dalam menjatuhkan putusan dalam suatu perkara yang sangat diutamakan adalah kesimpulan hukum terhadap fakta yang terungkap dalam suatu persidangan. Untuk itu hakim perlu memahami nilai-nilai hukum dan rasa keadilan yang hidup dalam masyarakat.

Hakim mempunyai kewajiban untuk memproses data yang diperoleh dari proses persidangan yang telah terjadi berdasarkan Pasal 164, "dilihat dari adanya bukti surat, saksi, persangkaan, pengakuan maupun sumpah" yang telah terungkap dalam persidangan. Sehingga keputusan yang dijatuhkan dapat didasari dari adanya tanggung jawab hakim, berdasarkan keadilan, berdasarkan kebijaksanaan dan profesionalisme.

Pokok Kekuasaan Kehakiman diatur dalam Undang-Undang Dasar 1945 Bab IX Pasal 24 dan Pasal 25 serta di dalam Undang-Undang Nomor 48 tahun 2009. UUD 1945 menjamin adanya suatu Kekuasaan Kehakiman yang bebas. 
Hal ini tegas dicantumkan dalam Pasal 24 terutama dalam penjelasan Pasal 24 ayat (1) dan penjelasan Pasal 1 ayat (1) UU No.48 Tahun 2009.

Bahwa pertimbangan hakim antara Soekotjo dan Melyani diperoleh faktafakta hukum sebagai berikut :

1. Kerjasama antara Penggugat selaku pemberi pinjaman modal usaha dan Tergugat sebagai penerima pinjaman modal adalah sah;

2. Perbuatan Tergugat yang tidak mengembalikan pinjaman modal pembelian gabah yang diberikan oleh Penggugat dinyatakan sebagai perbuatan cidera janji/wanprestasi;

3. Penyerahan jaminan milik Tergugat kepada Penggugat berupa tanah dan bangunan sesuai Sertifikat Hak Milik No.745/Kelurahan Blindungan, gambar situasi Np.1090, tanggal 23-12-1992, seluas $445 \mathrm{~m}^{2}$, terletak di Kelurahan Blindungan, Kecamatan Bondowoso, Kabupaten Bondowoso, atas nama Jusuf Eddy Sugianto (suami Tergugat) adalah sah dan mempunyai kekuatan hukum mengikat;

4. Sita jaminan yang diletakkan oleh Pengadilan Negeri Bondowoso terhadap Obyek Jaminan milik Tergugat, berupa sebidang tanah dan bangunan sesuai Sertifikat Hak Milik No.745/Kelurahan Blindungan, gambar situasi Np.1090, tanggal 23-12-1992, seluas $445 \mathrm{~m}^{2}$, terletak di Kelurahan Blindungan, Kecamatan Bondowoso, Kabupaten Bondowoso, atas nama Jusuf Eddy Sugianto (suami Tergugat) adalah sah dan berharga;

Jika melihat point $3 \& 4$, sudah jelas terjadi kekeliruan karena seharusnya sertifikat dianggap tidak ada. Karena di awal perjanjian tidak diperjanjikan bahwa apabila terjadi kemacetan dalam pelunasan hutang harus menyerahkan objek jaminan. Penggugat baru meminta Sertifikat Hak Milik kepada Tergugat setelah beberapa tahun sejak perjanjian itu dijalankan. 
Apabila hakim menyetujui gugatan Penggugat yang meminta ganti rugi berupa sertifikat adalah hal yang salah. Karena, sesuai dengan UU No. 4 Tahun 1996 tentang Hak Tanggungan menyebutkan bahwa jaminan hutang berupa tanah itu harus dipersyaratkan dengan Akta Pemberian Hak Tanggungan (APHT).

Seharusnya hakim tidak menyetujui, kalaupun bisa dijadikan sebagai alat untuk melunasi hutang tetapi mekanisme yang ada dalam UU Hak Tanggungan harus dilakukan terlebih dahulu dengan dibuat secara otentik yang dibuat oleh PPAT. Apabila digunakan sebagai jaminan harus dilakukan di depan PPAT, namun apabila sebagai bukti pelunasan harusnya dibuat langsung dalam bentuk jual beli tetapi pelunasannya dikonversi oleh hutang Tergugat. Apabila hakim memerintahkan Tergugat untuk menyerahkan jaminan berupa tanah harusnya dituangkan terlebih dahulu dalam suatu akta otentik yang dibuat PPAT yang namanya Akta Pembebanan Hak Tanggungan.

Apabila Hakim memerintahkan Tergugat untuk menyerahkan Sertifikat Hak Miliknya kepada Penggugat tanpa memenuhi syarat yang telah diatur dalam UU Hak Tanggungan, penyerahan tersebut dianggap menjadi sesuatu yang legal karena tidak sesuai dengan peraturan yang telah berlaku. Karena, bisa saja harga jumlah tanah lebih besar atau tidak sama harganya dengan jumlah hutang milik Tergugat.

Seharusnya hakim tidak menyetujui, kalaupun bisa dijadikan sebagai alat untuk melunasi tetapi mekanisme yang ada dalam UU Hak Tanggungan harus dilakukan dengan akta yang dibuat secara otentik yang dibuat oleh PPAT. Apabila sebagai jaminan harus dilakukan di depan PPAT, namun apabila sebagai bukti pelunasan harusnya dibuat langsung dalam bentuk jual beli tetapi pelunasannya dikonversi oleh hutang si tergugat. Apabila hakim memerintahkan tergugat untuk menyerahkan jaminan berupa tanah harusnya 
dituangkan dalam suatu akta otentik yang dibuat PPAT yang namanya Akta Pembebanan Hak Tanggungan.

Tapi APHT bukan menjadi dasar penggugat untuk mengambil tanah itu, karna untuk mengeksekusi harus mempunyai dasar hukum dalam bentuk sertifikat hak tanggungan. Sertifikat hak tanggungan tidak mungkin dapat diterbitkan apabila tidak ada APHT, dalam PP 24/1997 mengatakan bahwa setiap ada peralihan hak harus didaftarkan ke kantor pertanahan untuk dibuatkan tanda bukti hak tanggungan.

Setelah selesai baru diserahkan kepada kreditur, namun apabila sertifikat telah dipegang oleh kreditur dan debitur juga tidak membayar bisa dieksekusi. Tetapi kalau diambil begitu saja menjadi salah. Apabila hakim memerintahkan $\mathrm{C}$ dihukum untuk menyerahkan tanahnya kepada A sebagai pelunasan hutang tidak serta-merta surat itu dianggap legal tetap harus memenuhi mekanisme yang ada. Karna bisa saja jumlah tanahnya lebih besar daripada jumlah hutangnya. Saya melihat hakim tidak adil dengan $\mathrm{C}$, hutangnya hanya Rp.170.000.000,00 kalau kemudian tanah nya luas nya lebih besar dan dihitung dengan uang pasti harganya lebih mahal. Pertimbangannya sudah benar, namun putusan hakim yang menggugat $\mathrm{C}$ wajib menyerahkan hak milik atas tanahnya itu sudah tepat atau belum. Dibagian wanprestasinya benar namun dibagian penyerahan jaminan nya salah. Dalam kekuatan alat bukti, cukup 1 saja sudah cukup. Saksi tidak boleh hanya 1, harus lebih dari 1.

Maka dari itu, diperlukan keadilan dari Hakim untuk menyesuaikan dengan peraturan yang telah berlaku. Seperti yang dikatakan menurut pendapat Bapak Atalim, dalam pertimbangan hukum harus dicantumkan apa dasar keyakinan hakim dalam memutuskan perkara ini. Apabila hanya berdasarkan kepercayaan itu boleh, tetapi harus juga mempertimbangkan apabila terjadi masalah di kemudian hari. Maka dalam pertimbangan hukum, harus 
dicantumkan apa dasar keyakinan hakim tidak menggunakan maksimal alat bukti. Perjanjian lisan apalagi tertulis syarat sahnya perjanjian tetap dipenuhi, tetapi dengan menggunakan alat bukti nota, sertifikat hak milik sebagai jaminan maka ada cacat dalam hal tertentu untuk syarat sahnya perjanjian.

Dari situ sebenarnya perjanjian dapat batal demi hukum. Pertimbangan hakim tidak memenuhi karena hal tertentu syarat sah perjanjian tidak dipenuhi maka perjanjian batal demi hukum yaitu cacat dalam dasar menimbang hukum hakim sehingga kalau hakim hanya berpegang pada keyakinan dianggap lemah. Mengenai pertimbangan hakim, alat buktinya berupa saksi. Saksi nya tidak bisa digunakan karna saksi itu harus saksi yang mendengar langsung, melihat langsung dan mengalami langsung dengan apa yang telah disaksikannya. Satu orang saksi sama dengan tidak ada bukti karna itu harus 2, setelah ada satu orang saksi setelah itu harus ada pengakuan dari pihak tergugat jadi ada dua. Saksi yang digunakan oleh penggugat adalah saksi yang bekerja dengan penggugat dan tidak melihat secara langsung maka dari itu saksi tidak dapat digunakan/dipakai.

Berdasarkan hasil wawancara dan Analisa dari penulis, penulis berpendapat bahwa pertimbangan hakim dalam hal ganti rugi yang diderita oleh Penggugat yang meminta Tergugat untuk menyerahkan Sertifikat Hak Milik adalah salah. Karena di awal perjanjian Penggugat dan Tergugat tidak ada kesepakatan mengenai penyerahan Sertifikat Hak Milik sebagai objek jaminan pinjam Tergugat. Boleh sebetulnya apabila Penggugat meminta kepada Tergugat Sertifikat tersebut namun harus dalam bentuk APHT yang telah dibuat oleh PPAT. Karena bisa saja nilai sertifikat tersebut lebih besar dibanding uang yang dipinjam oleh Tergugat kepada Penggugat. Apabila nilai Serifikat tersebut lebih besar, maka Tergugat akan merasa dirugikan. Maka seharusnya harus dicantumkan apa yang telah manjadi dasar keyakinan hakim dalam 
memutuskan perkara hingga akhirnya hakim bisa yakin, karena apabila hanya berdasarkan dengan keyakinan hakim itu dianggap lemah. Seorang hakim seharusnya dalam mempertimbangkan suatu masalah seharusnya memikirkan kembali apabia terjadi perkara kembali akibat dari putusan hakim ini.

Hakim tidak membahas mengenai alat bukti yang seharusnya dijadikan sebagai salah satu dasar pertimbangan hakim. Karena, alat bukti tersebut merupakan salah satu dasar apakah terjadi suatu perjanjian atau tidak. Apabila hakim hanya berpegang pada keyakinannya tanpa mencantumkan apa dasar keyakinan hakim yang tidak mempertimbangan alat bukti dapat dikatakan cacat dalam dasar menimbang hukum. Kalau hakim hanya berpegang pada keyakinan nya dapat dianggap lemah.

\section{PENUTUP}

\section{A. Kesimpulan}

Pada bagian akhir skripsi ini, penulis akan memaparkan beberapa kesimpulan yang dapat diambil dan saran yang didasarkan pada temuan hasil penelitian. Secara umum penulis menyimpulkan bahwa:

1. Kelemahan dari perjanjian yang dilakukan secara lisan adalah memang betul dalam hal pembuktian. Maka dari itu kekuatan alat bukti dalam hal ini merupakan sesuatu yang penting untuk membuktikan apakah telah terjadi suatu perjanjian antara kedua belah pihak. Karna apabila, salah satu menyangkal kalau tidak pernah melakukan perjanjian tidak memiliki alat bukti yang kuat karena tidak dilakukan secara tertulis. Maka dari itu perlu ada nya hal-hal lain yang membuktikan bahwa benar telah terjadi perjanjian, setelah adanya bukti bahwa benar telah terjadi perjanjian setelah itu harus membuktikan bahwa benar jumlah yang ditagih oleh Penggugat bukan merupakan suatu rekayasa atau dilebih-lebihkan oleh Penggungat dengan maksud untuk mencari keuntungan. Dalam kasus ini, dapat dilihat bahwa alat 
bukti yang dapat digunakan adalah adanya pengakuan. Karena, saksi yang digunakan tidak dapat digunakan karna bukan merupakan saksi yang melihat dan mendengar di saat kejadian itu berlangsung. Melainkan, saksi tersebut adalah pekerja yang bekerja dengan Penggugat maupun Tergugat. Dan sebetulnya pengakuan dari Tergugat sudah cukup untuk menguatkan bahwa benar telah terjadi suatu transaksi pinjam meminjam uang untuk usaha dan Tergugat juga tidak menyangkal namun hanya membela diri dengan cara mengatakan bahwa ia juga mengalami kerugian tanpa maksud untuk mencari keuntunga sendiri serta ia juga mengatakan bahwa ia telah membayar bunga yang telah diajukan dari pihak Penggugat maka itu sudah merupakan alat bukti yang kuat bahwa benar telah terjadi Perjanjian antara Penggugat dan Tergugat.

2. Dasar pertimbangan hakim dalam menjatuhkan putusan perlu didasarkan pada teori dan hasil penelitian yang saling berkaitan sehingga didapatkan hasil penelitian yang maksimal dan seimbang dalam tataran teori dan praktek. Pertimbangan hakim dalam hal ganti rugi yang diderita oleh Penggugat yang meminta Tergugat untuk menyerahkan Sertipikat Hak Milik adalah salah. Karena di awal perjanjian Penggugat dan Tergugat tidak ada kesepakatan mengenai penyerahan Sertipikat Hak Milik sebagai objek jaminan pinjam Tergugat. Apabila hakim menyetujui gugatan Penggugat yang meminta ganti rugi berupa sertipikat adalah hal yang salah. Karena, sesuai dengan UU No. 4 Tahun 1996 tentang Hak Tanggungan menyebutkan bahwa jaminan hutang berupa tanah itu harus dipersyaratkan dengan Akta Pemberian Hak Tanggungan (APHT).Pertimbangan hakim dalam hal ganti rugi yang diderita oleh Penggugat yang meminta Tergugat untuk menyerahkan Sertifikat Hak Milik adalah salah. Karena di awal perjanjian Penggugat dan Tergugat tidak ada kesepakatan mengenai penyerahan Sertifikat Hak Milik sebagai objek jaminan pinjam Tergugat. Boleh sebetulnya apabila Penggugat meminta 
kepada Tergugat Sertifikat tersebut namun harus dalam bentuk APHT yang telah dibuat oleh PPAT. Karena bisa saja nilai sertifikat tersebut lebih besar dibanding uang yang dipinjam oleh Tergugat kepada Penggugat. Apabila nilai Serifikat tersebut lebih besar, maka Tergugat akan merasa dirugikan. Maka seharusnya harus dicantumkan apa yang telah manjadi dasar keyakinan hakim dalam memutuskan perkara hingga akhirnya hakim bisa yakin, karena apabila hanya berdasarkan dengan keyakinan hakim itu dianggap lemah. Seorang hakim seharusnya dalam mempertimbangkan suatu masalah seharusnya memikirkan kembali apabila terjadi perkara kembali akibat dari putusan hakim ini.

\section{B. Saran}

1. Berdasarkan hasil penelitian yang telah dilakukan oleh Penulis, semoga dapat berguna bagi orang lain yaitu seharusnya jika seseorang berniat untuk membuat suatu perjanjian yang dilakukan secara lisan, para pihak yang terlibat dalam perjanjian tersebut setidaknya perlu mempertimbangkan sebab akibat dari perjanjian yang dilakukan secara lisan tanpa adanya suatu bukti secara tertulis. Setidaknya, perjanjian tersebut dilakukan di depan orang lain sehingga apabila dikemudian hari ada yang melanggar perjanjian memiliki saksi yang dapat dibuktikan bahwa benar telah terjadi adanya perjanjian yang mengikat satu sama lain. Karena perjanjian yang dilakukan secara lisan sangat mudah untuk tidak diakui bahwa telah terjadi kesepakatan antara kedua belah pihak. Disarankan agar para pihak yang hendak membuat suatu perjanjian, tidak menggunakan perjanjian yang dilakukan secara lisan karena dapat menimbulkan kerugian yang cukup besar apabila terjadi wanprestasi. Apabila terdapat saksi, saksi tersebut dapat mencgah perjanjian lisan yang tidak diakui oleh kedua belah pihak. Apabila tetap tidak diakui, saksi dapat dijadikan sebagai alat bukti untuk membuktikan bahwa telah terjadi perjanjian lisan dalam persidangan. Bagi masyarakat, apabila ingin membuat perjanjian dalam bentuk lisan, para pihak perlu memprediksi terlebih 
dahulu mengenai akibat atau kerugian yang akan ditimbulkan jika terjadi wanprestasi. Karena, perjanjian lisan sangat mudah untuk disangkali atau tidak diakui. Apabila hubungan hukumnya kompleks dan dapat menimbulkan kerugian yang besar jika terjadi wanprestasi disarankan agar perjanjian tersebut dilakukan secara tertulis atau Perjanjian bawah tangan. Namun, lebih baik lagi apabila dilakukan di hadapan Notaris atau disebut juga Akta Otentik.

2. Bagi masyarakat yang sedang melakukan perjanjian lisan, sebaiknya mempunyai bukti yang cukup kuat untuk membuktikan bahwa benar telah terjadi adanya suatu perjanjian. Baik bukti berupa kwitansi, nota, maupun minimal 2 saksi yang melihat,mendengar, maupun terlibat langsung dalam perjanjian yang bertujuan untuk menguatkan dalil bahwa benar telah terjadi suatu perjanjian.

\section{DAFTAR PUSTAKA}

\section{A. Buku}

Fajar NDMukti, Achmad Yulianto. Dualisme Penelitian Hukum Normatif dan Empiris. Yogyakarta: PustakaBelajar, 2010.

Harahap, Yahya. Hukum Acara Perdata. Jakarta: Sinar Grafika, 1987.

Mahmud Marzuki, Peter. Penelitian Hukum. Jakarta: Kencana Prenada Media Group, 2010.

Subekti R, Hukum Perjanjian, Intermasa, Jakarta: Citra Aditya Bhakti, 1987. 